\title{
MEMOIRES, DIARIES, DIARY NOVELS ABOUT THE FIRST WORLD WAR IN HUNGARIAN LITERATURE ${ }^{1}$
}

\author{
ERIKA BENCE - LENKE KOCSIS
}

BENCE, Erika - KOCSIS, Lenke: Memories, Diaries, Diary Novels about the First World War in Hungarian Literature, 2019, Vol. 1, Issue 1, pp. 86 - 94. DOI: 10.17846/CEV.2019.01.1.86-94.

ABSTRACT: The paper aims to examine and interpret literary portrayals of the First World War in diary novels (Gábor Darvas), memoires (Rodion Markovits, Artúr Munk, Geiza Farkas), authentic diaries (Artúr Munk) and reminiscences (József Kozma) in Hungarian literature. Among these are bestsellers (Artúr Munk), confessions in novel form (Gábor Darvas), and a diary published on the occasion of the centenary (József K.). In the comparative analysis the relating novels of Jaroslav Hašek, Ernest Hemingway and Erich Maria Remarque are introduced as world literary points of reference.

KEYWORDS: Hungarian Literature. First World War. Analysis.

\section{THE FIRST WAVE OF 2OTH CENTURY WAR NOVELS IN HUNGARIAN LITERATURE}

In the retrospect, most significant era of literary works processing the events and traumas of the First World War began at the end of the 1920s and ended in the early 1930s. The patrioticheroic tones of propaganda literature could only be found in an ironic or satirical context in these works, the new take on the war was completely disillusioned and showed similarities with trench literature (Schoenberg - Trudeau, 2010). The interest in war novels decreased drastically by the end of the 1930s primarily due to certain literary-sociological changes (e.g. the decline of interest in the topic, the power of novelty faded), but the beginning of the Second World War contributed as well. Prior to this, immediately after the Great War, at the beginning of the 1920s just few novels and diaries were published in Europe, but only Jaroslav Hašek's (1883 - 1923) The Good Soldier Švejk (1923) had a larger impact. Hungarian literature has its share of forgotten directly post-war books, Ervin Bokor's Menekülés a szibériai fogságból [Escape from the Siberian Captivity] from 1919 and József Fleissig's Szibériai napló [Siberian Diary] published in 1920 both went unnoticed by the critics and remain underresearched.

Researches mainly referring to formal (political) dates (e.g. the constitution of the Kingdom of Serbs, Croats and Slovenes) and gathering data about post-war book publishing in the region of Vojvodina (Németh 2014, 2018) present János Tarkó’s novel titled Amíg a nagy vihar tombolt... [While the great storm raged...] as the first post-war novel of Hungarian literature based mainly on the fact that the book was published in 1919. Other theoretical-poetical analyses (Bence 2017,2018) modulate and disapprove these claims based on chronological facts and thematic classification. In fact, when we examine the descriptions of landscapes and the presentation of the habits of the rural middle class, the While the great storm raged... seems more closely related to French and Hungarian late-romantic literature and the work of local (Vojvodina) writer Dániel Papp ${ }^{2}$, than its contemporaries which are regarded by some researchers as new literary endeavours induced

\footnotetext{
Certain segments of the research were published previously (Bence 2015, 2015a, 2017, 2017a, 2017b, 2018) and will be referenced accordingly.

The titles of the novels that do not have an official English translation and the citations from texts only available in Hungarian were translated by the authors of the paper.

2 Dániel Papp, 1899. Tündérlak Magyarhonban [Fairy-lodge in Hungary]. Author’s edition.
} 
by post-war socio-political circumstances (Csáky 1988, 18; Németh 2018, 133). The narrator of Tarkós novel is completely ignorant about the changes of the world that occurred during and after First World War, nor does he care about the freshly realigned political structures. This stagnant world view can be observed in other Hungarian literary works from the beginning of the 1920s as well (Bence 2018, 102). Furthermore, the style and phrasing of Tarkós novel does not show any similarities with other war novels of the era. Although the plot is set during the time of the First World War, the historical event itself serves only as the setting of the story. The war literally passes over the Colbert ${ }^{3}$ family who due to their humane convictions refuse to participate in the massacre and retreat to a cave where they create utopia celebrating science, culture and democracy. While the great storm raged... has literary connections to Mór Jókai’s (1825 - 1904) late-romantic novel about coalmining, Black Diamonds (1970), and the works of Jules Verne (1823 - 1905), "mostly his novels with underground settings (first and foremost The Child of the Cavern (1877)) could have influenced Tarkó, also certain passages, like the creation of an isolated world with the help of science, or the tale of the organ builder indicate inspiration from the Carpathian Castle (1892)" (Bence 2017, 89).

\section{A MORE CRITICAL APPROACH}

The second wave of the First World War novels emerged approximately 10 years later, at the end of the 1920s and carried on until the mid-1930s. According to Löhrke, the publishers and the public showed little to no interest in war literature in the first half of the 1920s, and some books on the topic published in that period went completely unnoticed (Löhrke 1930, 15 - 17). Compared with the first adaptations of the topic, these books approached the events of the war in far more critical tone. The observations, the consequences and the viewpoint provided by the perspective of a decade all contributed to the creation of authentic narratives that came with a need to confess personal experiences, to dissolve trauma into fiction, as Lejeune described the act, " $t$ to release, to unload the weight of emotions and thoughts in putting them down on paper" (Lejeune 2009, 194). The two (until the present day) internationally renowned novels of the era are Erich Maria Remarque's All Quiet on the Western Front and Ernest Hemingway's A Farewell to Arms. Both books were published in 1929 and brought worldwide recognition, and commercial success to the writers. The examined novels, diaries, and memoires from Hungarian literature (from Hungary, Transylvania [Romania] and Vojvodina [Serbia]) are also to be analysed in this contexts. The re-emergence of militant ambitions in Western Europe and the formation of Hungarian literary establishments (magazines, organizations, publishers) in Vojvodina presumably both contributed to the appearance of novels in the region thematizing the Great War at the beginning of the 1930s. Artúr Munk (1886-1955) published two novels, A Nagy káder [The Great Cadre] (1930) and A hinterland: A mögöttes országrész háborúja [The Hinterland: The War of the Countryback] (1933). Gábor Darvas (18891972) wrote a diary novel "Mindent meggondoltam és mindent megfontoltam..." ["I have examined and weighed everything...”] (1930). Two chapters of István Szabós (?) and Dezső Andrée’s (18951944) adventure novel Egy legionista naplója: Hat esztendő a Francia Idegenlégióban [Diary of a Legionary: Six Years in the French Foreign Legion] (1931) take place during the war. The novel of Geiza Farkas, A fejnélküli ember [The Headless Man] (1933) tells the story of a man suffering from post-traumatic stress disorder and going insane.

The story takes place in Champagne, France on a family estate somewhere along the river Aisne. The head of the family is the descendent of 17th century French statesman Jean-Baptiste Colbert (1619-1683) who was interested philosophy and technical sciences. 
The world-renowned and the most successful war novel of the Hungarian literature Siberian Garrison (1927) had been forgotten and rediscovered later. The "collective reportage novel" (as the author defined his work ${ }^{4}$ ) was written by Rodion Markovits (1888 - 1948), a Jewish-Hungarian journalist from Transylvania, who was held in the same war prison camp in Krasnoyarsk (Siberia, Russia) as Hašek. Based on their work they had very similar experiences, but there is no proof of them being acquainted or that Markovits was familiar with the Švejk books ${ }^{5}$. The Siberian Garrison was first published in Cluj (Romania), but only the second edition from 1928, that was released in Budapest (Hungary), brought recognition to the author and over the years it has been translated into fourteen languages. While trying to understand the reasons behind the surprising critical and commercial success of the Siberian Garrison, János Szekernyés analysed the sociological background and hermeneutical characteristics of the era: "By the end of the 1920s the first era of war literature came to an end, addressing, analysing, and clarifying the problematic topic of 'responsibility'. Thousands of memoires, pamphlets, novels, military studies, and political discussion were written about the causes, course, major battles, dramatic consequences, the dictatorial peace treaties, etc. of the First World War. By the end of the 1920s sufficient time has passed to enable an open and unbiased retrospection free of nationalism. The social and political changes provided a new opportunity for a deeper understanding and explanation of certain war events, at the same time beyond the act of sharing subjective experiences the recognition and awareness of the collective tragedy of mankind became apparent" (Szekernyés 2011, 52). The main character of the Siberian Garrison is an outsider similar to Švejk (Hašek), Paul Braumer (Remarque) or Frederic Henry (Hemingway). The unemployed jurist/journalist of Markovits, like the other hundreds of thousands of enlisted soldiers, is ignorant to the global scale of devastation the war will bring. In the beginning he believes to be fighting for a 'just cause', not realizing he has been 'cheated. The resemblance of the characters, the presented topics and motifs are important since these novels were all written at the same time (not including Švejk) and thereby the possibility of intertextual relations or plagiarism can be excluded.

The sequel of the Siberian Garrison titled Aranyvonat [Gold Train] was based on the time that Markovits spent in the ranks of the Red Army as a member of the 1st International Brigade guarding a train that transported the gold reserves of the State Bank of the Russian Empire. The Gold Train was received with displeasure by the critique; it was constantly compared to the Siberian Garrison and judged by the merits of its predecessor, for example in the review of Károly Molter published in the Erdélyi Helikon (Molter 1930). The swift success and sudden unpopularity of Markovits resulted in the creation of negative legends about the writer's boorish personality, describing him as a rapacious country bumpkin with addictive behaviours and interpreting his fall as the result of jokes based on Jewish stereotypes. Although Markovits came from a family of orthodox Jews, he himself was assimilated, but due to growing anti-Semitism at the beginning of the 1930s a smear campaign was launched against his person. The paradox of the story is that the qualities of the Gold Train, like the (compared to the Siberian Garrison) more polished concept, the poetical innovations, the refined ideological orientation could all have been discovered by its contemporary reviewers if they had stayed objective. Furthermore, the contemporary literary discourse preferred intellectual prose; consequently the Black Monastery (1931) by Aladár Kuncz (1885 - 1931), a more sophisticated novel depicting life in a French internment camp resonated much better with the critiques. Based on the 21st century research (Hammerstein 2011, Szekernyés

Markovits published a call in the newspaper Keleti Újsági inviting war veterans to share their stories and experiences, hundreds came forward. Instead of publishing the interviews in a documentary Markovits merged these with his own experiences, constructed a narrative, and created a novel (Bence 2018, 39).

5 The first Hungarian translation of the Švejk stories was published in 1930. 
2011, Dénes 2013, Baliga 2014, Bence 2018) the rejection of the second novel was also a result of literary-sociological factors, the sequels written by other authors during this period had a similar reception. For instance The Hinterland, the second novel of Artúr Munk, met the same fate as the Gold Train. Its contemporary reviewers and readers rejected it, although now it is considered to be the more accomplished novel of the two. It was the second edition of The Hinterland in 1981 (with an afterword by Imre Bori) that appointed the novel to its rightful place in the history of Hungarian literature from Vojvodina. By examining the reception of works written by worldrenowned authors like Remarque, it can be concluded that other war novel sequels were also overshadowed by their predecessors, for instance The Road Back (1931) was not even nearly as successful and well received as All Quiet on the Western Front (Bence 2018, 50).

\section{HUNGARIAN WAR NOVELS FROM VOJVODINA}

War novels published at the beginning of the 1930s were an important stage in the evolution of Hungarian literature of Vojvodina. The existence of these books serves as proof that the newly formed cultural community was susceptible to, and knowledgeable regarding the literary developments of the time. The novels served as an instrument of reckoning with the past and at the same time enabled to process traumas caused by the war. Through the act of telling their experiences, articulating thoughts and opinions all the following authors aimed to close the era. The first Hungarian author from Vojvodina who publish a book that can be interpreted in the literary context of First World War novels was Artúr Munk, an adventurer with his very own (somewhat heroic) local legendary. In 1912 he was travelling on board of the ocean liner Carpathia, one of the ships that helped the distressed passengers of the Titanic after the catastrophic event. Local stories say that Munk was part of the medical staff, depicting him in a more heroic pose, as a simple passenger (although we have to add, earlier he had actually worked on other ocean liners). Munk, who entered the Austro-Hungarian Army as a volunteer, was captured by the Red Army and survived the horrors of the prison camps because of his value as a medical doctor. His first war novel The Great Cadre was written based on his front line and internment camp experiences; it was a success, praised by critiques and popular with the readers. The Hinterland, as described above, was not well received and had been overlooked for decades, although it had a very critical, sometimes ironic tone and a rather grotesque perspective unveiling the outrageous and preposterous nature of war time events and human behaviour. The Hinterland is a story of a young man who spends most of the war far away from the front lines due to some minor injuries, luck and the good will of a few doctors, just to die an utterly meaningless death in the last hours of the war. Conversations taking place in medical and military facilities in the country back confront the reader with propaganda, critical opinions and long concealed socio-political problems. In 1999, the diaries written by Munk on the frontline proof that his novels were based on actual events ${ }^{6}$.

In 1914, at the beginning of the war, Gábor Darvas, a 25-year-old Jewish engineer, was serving his mandatory military service in the Austro-Hungarian Army, so he was sent to the frontlines right away. Darvas fell ill with typhoid and was left behind in the field hospital during a retreat. The advancing army of the Serbian Kingdom took over the abandoned facilities and the patients became prisoners of war. During the retreat of the Serbian armed forces across the mountains of Albania, the prisoners were forced to march alongside the army and were later taken over by the Allies. Darvas returned home from France in the mid 1920s. In 1935 he emigrated to Haifa (Palestine at the time). Beyond the few short stories published after his war novel we have no knowledge of him ever writing again (Kalapis 2002, 217 - 218). The title of Darvas's novel

6 Munk, Artúr. 1999. Napló (1915-1916). Szabadka: Szabadegyetem. 
I have examined and weighed everything... is in fact a citation from the manifesto "To my Peoples!" (Various Authors 2005, 226) that was signed by Franz Joseph I, Emperor of Austria-Hungary in 1914. This declaration announced the war on Serbia, starting the First World War. It is unclear how much of the novel's plot is based on actual events, the little amount of information we have on the life of Darvas might have at least partially been derived from the book, since the available biographical data is extremely similar to the plot of I have examined and weighed everything... The book's diary-like structure suggests that Darvas might have had original diaries. Among the depictions of cruelty, illness, misery, famine, and suffering the romantic episode of the AustroHungarian soldier and the Serbian girl stands out almost unnaturally. It seems like Darvas wanted to somehow counterpoint the gruesome reality of the war with something as ordinary and miraculous as a romance. As the story progresses the characters are confronted with different life threatening situations and the moral dilemmas. The question how to preserve one's humanity amongst impossible circumstances lingered constantly.

The journalist Dezső Andrée (1895 - 1944) supposedly met István Szabó in Paris in 1926 and obtained Szabós diaries written during his journeys through Europe, North Africa, the time spent in the army in the First World War, and the years spent in the French Foreign Legion. Adrée was executed as a fascist on a false accusation in 1944 (Kalapis 2002, 41 - 42). The Diary of a Legionary obviously differs from the previously discussed books, since it is an adventure novel with a plot only partially set during the time of the First World War. We assume that the other author István Szabó is a fictional character created by Andrée, because there is no information available about his identity; furthermore, 'Stephen Smith' is one of the most common combinations of Hungarian first and last names. This makes István Szabó practically unidentifiable. The last two chapters of the first volume tell the story of how the main character was enlisted into the Austro-Hungarian Army, got captured by the Russians and managed to escape. The circumstances described in the internment camp episodes are extremely similar to Munk's and Markovits's descriptions.

Among the discussed works from Vojvodina that were published in the early 1930s the novel of Geiza Farkas (1874 - 1942) definitely stands out. The author was a 20th century polymath who studied law, furthermore wrote papers in the fields of sociology, psycho-sociology, and philosophy. Before Farkas wrote The Headless Man he discussed the psycho-sociological reasons behind the First World War in some of his studies ${ }^{7}$, these in fact deliver a scientific and philosophical background to the novel (Bence-Németh 2015, 13 - 14). The title character is a headless demon that plagues György Nagybáti, a respectable family man and wealthy merchant in the present, who acquired his capital by dishonourable means during wartime. Farkas most likely got the inspiration for the representation of Nagybáti's guilt and trauma from the popular gothic horror story by Washington Irving (1783 - 1859) titled The Legend of Sleepy Hollow (ibid., 24 - 25). As the story progresses, the main character is slowly driven mad by the headless man. The reasons behind Nagybáti's condition unfold little by little in hazy flashbacks: as a young man he fled the frontline, met a travelling merchant on the road who recognized him as a deserter and killed him out of fear. The Headless Man might be the first representation of post-traumatic stress disorder and its consequences in Hungarian literature. While the novels of Munk, Darvas and Andrée

Farkas Geiza, 1914. A háború lélektana: az idő harcokat újráz. http://sites.google.com/site/ azidoharcokatujraz/home/szarajevo-kavehaz/farkas-geiza-a-haboru-lelektana.

Farkas Geiza, 1916. Az emberi csoportok lélektana. Budapest: Grill Károly Könyvkiadóvállalata. http:// mtdaportal.extra.hu/books/farkas_geiza_az_emberi_csoportok_lelektana.pdf

Farkas Geiza, 1923. Démonok közt. Társadalom-lélektani tanulmány. Budapest: Grill Károly Könyvkiadóvállalata.

Farkas Geiza, 1925. A társadalmi lélektan köréből. Három előadás. Velikibecskerek: Pleitz. 
explored the reasons and showed the nature of war traumas suffered on the frontline and in the internment camps, none of them examined the long lasting effects like Farkas did. The Headless Man was also the first book published by the literary movement 'Kalangya' [Grain Shock] in their series Kalangya Könyvtár [Grain Shock Library] (Kalapis 2002, 281).

As already mentioned before, the interest in First World War novels declined by the beginning of the 1940s. Perhaps the most internationally well known work on the topic from these years is Dalton Trumbo's Johnny Got His Gun (1939), although its later film adaptations (1971, 2008) and other appearances in popular culture certainly made the novel more accessible for later generations than any other of its contemporaries. In Johnny Got His Gun all the horrors of the war and its aftermath are condensed in the mutilated body of Joe Bonham, a "conscious corpse" (Blackmore 1999, 4). This anti-war novel displays not only a critical tone but aspires to serve as a deterrent example as well, likely brought into existence by the events leading up to the outbreak of the Second World War. These same conditions must have inspired József Kozma (1897 - 1969), a carpenter from Novi Sad to write about the years he spent on the front lines in the First World War twenty years later in 1940. Kozma was still a minor when he ran away from home to join the supply corpse at the beginning of the war in 1914, so he was already familiar with life on the frontlines when he was enlisted in the ranks of the Austro-Hungarian Army in 1916 (Csorba - Örkész 2010, 200; 2010a, 171). The memoire was passed down as a family heirloom and was finally published posthumously in 2014 on the occasion of the centenary with the title "Pedig én katona akartam lenni” K. József visszaemlékezései a Nagy Háborúra, 1914 - 1918 ["But I wanted to be a soldier" the memoire of József K. on the Great War, 1914 - 1918]. The events of the book follow strict chronological order, this suggests that Kozma either had a diary or some kind of records written previously or even on the frontlines. The family members of Kozma insisted on concealing his identity by making only the initial of his family name public, since they were concerned about retribution. Their fears proved to be irrational.

\section{RECURRING TOPICS AND MOTIFS IN THE WORKS FROM VOJVODINA}

All these authors aimed to create their own wartime narratives; however, they have a few reoccurring topics with surprisingly similar representation. As already established above, Darvas choose a citation from Franz Joseph's 1914 manifesto as the title of his novel. The same sentence is referenced again at the end of the book with a much more bitter and ironic connotation, indicating that the emperor's words lost their credibility: "Legalább az a két minden ne lett volna benne... [If only those two everythings had not been in it]" (Darvas 1930, 280), additionally making fun of the emphasis put on the word 'everything' in the Hungarian translation. Munk's reference of the declaration in his second novel The Hinterland was critical from the start, the phrase is ridiculed in a conversation between soldiers: "Ezt ugyan őfelsége jobban is meggondolhatta és megfontolhatta volna... [His majesty could have examined and weighed everything more thoroughly...]" (Munk 1981, 17). Darvas also referenced a speech of Wilhelm II addressing the German soldiers departing for the frontline in 1914: "Mire a levelek lehullanak a fákról, mindannyian otthon leszünk... [We will all return home before the leaves fall from the trees]" (Darvas 1930, 5). The characters of Munk and Darvas believed the propaganda at the beginning; this blind trust is also mirrored in the enthusiasm of the young Kozma at beginning of his memoire, along with the bizarre recurring exclamation in the first chapter of The Hinterland "Éljen a háború! [Long live the war!]" (Munk 1981, 5). At some point Munk, Darvas and Kozma all discuss how easily people were influenced by the propaganda, how almost everybody believed everything the newspapers wrote, how nobody even bothered questioning those "truths" and how they were fully convinced that the cause they were fighting for was rightful cause. The disillusionment came only when the errors 
in judgement became apparent. The incompetence of the general staff of the Austro-Hungarian Army is depicted several times. In the second chapter of The Hinterland titled "Tüntető felvonulás a Száva partján [Demonstration on the shore of the river Sava]" the army is marched up and down the river shore, because the general staff deemed this to be the most efficient way to demonstrate the power of the army; of course the only thing achieved was exhausting the soldiers (ibid., 11). Another outrageously absurd affair in Munk's novel is told in a hospital by an injured soldier: food storage was rather set on fire than to feed starving men, because no orders were given to distribute the reserves (ibid., 34). This delusional and pretentious attitude common among the Austro-Hungarian aristocrats, who formed the general staff of the Austro-Hungarian Army is also unintentionally portrayed in the dairy of countess Ilona Andrássy that was published with the title Mindennek vége! [All has come to an end!] in 2015. Thus, even if involuntarily, it validates the critical tones of the other books.

These authors returned to their homes in the early 1920s; at that time neither the AustroHungarian Monarchy nor any other circumstances were the same as when they left. The Hungarian intellectual communities in the disannexed territories had to redefine themselves as they were no longer on the periphery of a culture. These First World War novels served a dual purpose. By writing about topics and in a style that corresponded with the contemporary European literary trends and subjects they all contributed to the establishment and development of their local minority culture. On the other hand, by confronting the problematic topics surrounding and traumas caused be the First World War, they took on an active role in processing painful events.

\section{REFERENCES}

Andrássy, Ilona, 2015. Mindennek vége! Andrássy Ilona grófnő első világháborús naplója. Budapest: Európa Könyvkiadó.

Baliga, Violetta Lilla, 2014. Egy szibériai tartalékos zászlós mindennapjai. Markovits, Rodion: Aranyvonat. In: Pro Minoritate 2014/nyár, 121 - 123. www.prominoritate.hu/folyoiratok/2014/ ProMino-1402-beliv-09-baliga.pdf.

Bence, Erika, 2015. Katonaregények. A másfél évtizedes rálátási távlat. In: Létünk 45. (3), Novi Sad: Forum, 129 - 133.

Bence, Erika, 2015a. Az első világháború tematizációja az 1930-as évek vajdasági magyar irodalmában. In: Virtuális irodalomtörténet. Veszprém: Iskolakultúra, 102 - 113.

Bence, Erika, 2017. "Sci-fi" a háborúban. Tarkó János: Amíg a nagy vihar tombolt. In: Miért sír Szulimán? Elemzések, bírálatok a magyar irodalom köréből. Budapest: Cédrus Müvészeti Alapítvány-Napkút Kiadó, 85 - 102.

Bence, Erika, 2017a. Egy legionista a háborúban. Szabó István-Andrée Dezső: Egy legionista naplója. Hat esztendő a Francia Idegenlégióban (1923 - 1929). In: Miért sír Szulimán? Elemzések, bírálatok a magyar irodalom köréböl. Budapest: Cédrus Müvészeti Alapítvány Napkút Kiadó, 117 - 145.

Bence, Erika, 2017b. Napló (regény) az első világháborúból. Darvas Gábor: “Mindent meggondoltam és mindent megfontoltam...” In: Miért sír Szulimán? Elemzések, bírálatok a magyar irodalom köréből. Budapest: Cédrus Művészeti Alapítvány - Napkút Kiadó, 103 - 117.

Bence, Erika, 2018. Vajdasági magyar irodalmi lexikon. In: Napút Online. http://www.naputonline. hu/2018/01/07/bence-erika-vajdasagi-magyar-irodalmi-lexikon-1918-2014/.

Bence, Erika, 2018a. Magyar bestsellerek, irodalmi (világ)sikerek a két világháború között. In: Hungarológiai Közlemények 49/19 (2). Novi Sad: University of Novi Sad, Faculty of Philosophy, Department of Hungarian Studies, 34 - 55. 
Bence, Erika - Németh Ferenc, 2015. Farkas Geiza «A fejnélküli ember’ című regényének európai kulturális kontextusa. In: Godišnjak Filozofskog fakulteta u Novom Sadu. University of Novi Sad, Faculty of Philosophy, $11-30$.

Blackmore, Tim, 2000. Lazarus Machine: Body Politics in Dalton Trumbo's “Johnny Got His Gun”. In: Mosaic: An Interdisciplinary Critical Journal Vol. 33, No. 4., 1 - 18. https://www.jstor.org/ stable/44029705.

Bokor, Ervin, Dr., 1919. Menekülés a szibériai fogságból. Japánon és Anglián keresztül/Két magyar tiszt viszontagságai. Budapest: Franklin - Társulat Magyar Irod. Intézet és Könyvnyomda.

Csáky, S. Piroska, 1988. Vajdasági magyar könyvek 1918-1941. Novi Sad: Forum.

Csorba, Béla, 2015. Kozma József könyvéről. In: Létünk 45 (3). Novi Sad: Forum, 127 - 129.

Csorba, Béla - Ökrész Károly, 2010. Kozma József emlékei az első világháborúból I. In: Létünk, 2., 199 - 212. Novi Sad: Forum.

Csorba, Béla - Ökrész Károly, 2010a. Kozma József emlékei az első világháborúból II. In: Létünk, 3., 171 - 184. Novi Sad: Forum.

Darvas, Gábor, 1930. “Mindent meggondoltam és mindent megfontoltam...”. Novi Sad: Uránia.

Dénes, Gabriella, 2013. Markovits Rodion írói arcai. In: Látó. http://www.lato.ro/article.php/ Markovits-Rodion-írói-arcai/2741/.

Fleissig, József, 1920. Szibériai napló. Fogságom és szökésem. Budapest: Benkő Gyula cs. és kir. Könyvkereskedése.

Hašek, Jaroslav, 1961. Švejk, a derék katona kalandjai a világháborúban. transl. Réz Ádám. Budapest: Magyar Helikon.

Hašek, Jaroslav, 1996. Švejk, a derék katona a háború előtt és más furcsa történetek. Szerk. Hunyadi Csaba. Ford. Bába Iván, Mayer Judit, Tóth Tibor. Szeged: Szukits.

Hammerstein, Judit, 2011. Egy elfelejtett magyar világirodalmi bestseller (Markovits Rodion: Szibériai garnizon). In: Látó. http://www.lato.ro/article.php/Egy-elfelejtett-magyarvilágirodalmi-bestseller-Markovits-Rodion-Szibériai-garnizon/2092/.

Hemingway, Ernest, 2006. Búcsú a fegyverektől. transl. Örkény István. Szeged: Könyvmolyképző Kiadó.

Kalapis, Zoltán, 2002. Életrajzi kalauz. A-GY. Novi Sad: Forum.

K. József, 2014. "Pedig én katona akartam lenni". K. József visszaemlékezései a Nagy Háborúra 1914 - 1918. Novi Sad - Temerin: Forum - Temerini Múzeumbarátok Egyesülete.

Kuncz, Aladár, 1931. Fekete kolostor. Feljegyzések a francia internáltságból. Cluj: Erdélyi Szépmíves Céh.

Lejeune, Philippe, 2009. On diary. Ed. Popkin, Jeremy D. - Rak, Julie. transl. Durnin, Katherine. Manoa: University of Hawaii.

Löhrke, Eugene, 1930. Armageddon: The First World War Literature. USA: J. Cape and H. Smith.

Markovits, Rodion, 1986. Szibériai garnizon. Kollektív riportregény. Budapest: Ifúsági Lap - és Könyvkiadó Vállalat.

Markovits, Rodion, 1929. Aranyvonat. Budapest: Genius kiadás.

Molter, Károly, 1930. Markovits Rodion: Aranyvonat. In: Erdélyi Helikon 3 (1), Cluj: Erdélyi Szépmíves Céh, 82 - 85.

Munk, Arthur, 1930. A nagy káder. Egy pleni feljegyzései a forradalmi Oroszországból. Budapest: Pantheon Kiadás.

Munk, Artúr, 1981. A hinterland. A mögöttes országrész háborúja. Újvidék: Forum Könyvkiadó.

Munk, Artúr, 1999. Napló 1915 - 1916. Szabadka: Életjel.

Németh, Ferenc, 2014. A Nagy Háború (ismeretlen) regénye. Tarkó János: Amíg a nagy vihar tombolt... In: Tanulmányok, 1., Novi Sad: University of Novi Sad, Faculty of Philosophy, Department of Hungarian Studies, 100 - 109. 
Németh, Ferenc, 2018. 1919: A kisebbségi, irodalmi öneszmélés éve Nagybecskereken. In: Hungarológiai Közlemények, 59/19 (3), Novi Sad: University of Novi Sad, Faculty of Philosophy, Department of Hungarian Studies, 128 - 138.

Remarque, Erich Maria, 1929. Nyugaton a helyzet változatlan. Transl. Benedek Marcell. Budapest: Európa.

Schoenberg, Thomas - Trudeau, Lawrence ed., 2010. Twentieth-century Literary Criticism vol. 226. Detroit, Michigan: Gales.

Szabó, István - Andrée, Dezső, 1931. Egy legionista naplója. Hat esztendő a Francia Idegenlégióban (1923 - 1929). Ed. Andrée Dezső. Novi Sad: Uránia.

Szekernyés, János, 2011. Egy világsiker eredői, összetevői és utórezgései. Markovits Rodion és kollektív riportregénye a szibériai hadifogságról. In: Múlt és Jövő 26 (3), 51 - 73. www.multesjovo.hu/hu/aitdownloadablefiles/download/aitfile/aitfile_id/1437/.

Tarkó, János, 1919. Amíg a nagy vihar tombolt... Nagybecskerek: Haász Testvérek.

Trumbo, Dalton, 1959. Johnny Got His Gun. New York: Bantan Books.

Various, Authors, 2005. Current History: The European War. From the Beginning to March 1915. New York: New York Times. http://www.gutenberg.org/files/16331/16331-h/16331-h.htm.

\section{CONTACT}

Dr. Erika Bence

Lenke Kocsis

University of Novi Sad, Faculty of Philosophy

Department of Hungarian Studies

Dr Zorana Đinđića 2

21000 Novi Sad

Serbia

erika.bence1967@gmail.com,

lenkeko@gmail.com 